\title{
Brain tissue partial pressure of oxygen predicts the outcome of severe traumatic brain injury under mild hypothermia treatment
}

This article was published in the following Dove Press journal:

Neuropsychiatric Disease and Treatment

24 August 2016

Number of times this article has been viewed

\section{Hongtao Sun ${ }^{1, *}$ \\ Maohua Zheng',* \\ Yanmin Wang' \\ Yunfeng Diao' \\ Wanyong Zhao' \\ Zhengjun Wei'}

'Sixth Department of Neurosurgery, Affiliated Hospital of Logistics University of People's Armed Police

Force, Tianjin, ${ }^{2}$ Department of

Neurosurgery, The First Hospital of Lanzhou University, Lanzhou,

People's Republic of China

*These authors contributed equally to this work
Correspondence: Hongtao Sun Sixth Department of Neurosurgery, Affiliated Hospital of Logistics University of People's Armed Police Force, 220 Chenglin Road, Hedong District, Tianjin 300162, People's

Republic of China

Tel +86226057 7l42

Email sunhongtao2016@163.com
Objective: The aim of this study was to investigate the clinical significance and changes of brain tissue partial pressure of oxygen $\left(\mathrm{P}_{\mathrm{bt}} \mathrm{O}_{2}\right)$ in the course of mild hypothermia treatment (MHT) for treating severe traumatic brain injury (sTBI).

Methods: There were 68 cases with sTBI undergoing MHT. $\mathrm{P}_{\mathrm{bt}} \mathrm{O}_{2}$, intracranial pressure (ICP), jugular venous oxygen saturation $\left(\mathrm{S}_{\mathrm{jv}} \mathrm{O}_{2}\right)$, and cerebral perfusion pressure (CPP) were continuously monitored, and clinical outcomes were evaluated using the Glasgow Outcome Scale score.

Results: Of 68 patients with sTBI, $\mathrm{P}_{\mathrm{bt}} \mathrm{O}_{2}, \mathrm{~S}_{\mathrm{jv}} \mathrm{O}_{2}$, and CPP were obviously increased, but decreased ICP level was observed throughout the MHT. $\mathrm{P}_{\mathrm{bt}} \mathrm{O}_{2}$ and ICP were negatively linearly correlated, while there was a positive linear correlation between $\mathrm{P}_{b t} \mathrm{O}_{2}$ and $\mathrm{S}_{\mathrm{jv}} \mathrm{O}_{2}$. Monitoring CPP and $\mathrm{S}_{\mathrm{jv}} \mathrm{O}_{2}$ was performed under normal circumstances, and a large proportion of patients were detected with low $\mathrm{P}_{b t} \mathrm{O}_{2}$. Decreased $\mathrm{P}_{b t} \mathrm{O}_{2}$ was also found after MHT.

Conclusion: Continuous $\mathrm{P}_{\mathrm{bt}} \mathrm{O}_{2}$ monitoring could be introduced to evaluate the condition of regional cerebral oxygen metabolism, thereby guiding the clinical treatment and predicting the outcome.

Keywords: severe traumatic brain injury, hypothermia, brain tissue partial pressure of oxygen, therapy

\section{Introduction}

Monitoring the function and metabolism of the brain has proved to be a key factor in the treatment of patients with severe traumatic brain injury (sTBI). Currently, routine parameters for detecting the oxygen content and blood supply in brain tissue include intracranial pressure (ICP), cerebral perfusion pressure (CPP), transcranial Doppler ultrasound, and jugular venous oxygen saturation $\left(\mathrm{S}_{\mathrm{jv}} \mathrm{O}_{2}\right)$. However, the application of these monitoring parameters in clinical practice is quite limited. ${ }^{1}$ It is well known that the metabolic enzyme activity in brain tissue is not equal and TBI may only induce local oxygenation dysfunction. Thus, the overall oxygenation of the brain could be within the normal range after TBI, which is unable to obtain an objective evaluation on the local oxygenation. In addition, local oxygen content monitoring has already become the focus in this research field all over the world. The detection of brain tissue partial pressure of oxygen $\left(\mathrm{P}_{\mathrm{bt}} \mathrm{O}_{2}\right)$ level is getting more and more attention from clinicians. As a new monitoring method, $\mathrm{P}_{b t} \mathrm{O}_{2}$ has the advantage of reflecting the local oxygenation of brain tissue over other parameters. ${ }^{2}$

Experimental and clinical studies have reported that mild hypothermia treatment (MHT) has a protective effect on the brain function and metabolism, which could reduce 
a series of adverse effects, prevent the occurrence of increased ICP, and minimize the consequent injury. ${ }^{3-5}$ In this study, we combined the evaluation of MHT efficacy with oxygen monitoring in the management of patients with sTBI. The parameters including $\mathrm{P}_{\mathrm{bt}} \mathrm{O}_{2}, \mathrm{~S}_{\mathrm{jv}} \mathrm{O}_{2}, \mathrm{ICP}$, and CPP were continuously detected, and their correlations were also evaluated in order to further investigate the effect of MHT on the oxygenation in the brain tissue. These results may help guide the selection of clinical strategy and predict the outcome for sTBI.

\section{Methods}

\section{Patients}

A total of 68 patients with sTBI who underwent MHT from August 2010 to September 2011 in our center were enrolled. Inclusion criteria were that the patients who were diagnosed with acute sTBI (Glasgow Coma Score $\leq 8$ at admission), and the traumatic time was defined as the time since the accident was $<3$ hours. Patients with severe lung, abdominal, or other injuries, severe cardiac arrhythmia, coronary heart disease, and diabetes mellitus were excluded. Written informed consent was obtained from all the patients. This study was approved by the ethics committee of the Affiliated Hospital of Logistics University of People's Armed Police Force.

\section{Mild hypothermia treatment}

During MHT, the room temperature was set at $17^{\circ} \mathrm{C}$. The patients were asked to lie on the temperature-controlled blanket (Blanketrol II; CSZ, Cincinnati, OH, USA) for physical cooling, and the habination mixture of $100 \mathrm{mg}$ chlorpromazine and $100 \mathrm{mg}$ promethazine in $500 \mathrm{~mL}$ water or sedative drug of morphine sulfate in $100 \mathrm{~mL}$ water was administrated by intravenous injection to decrease the rectal temperature to $35^{\circ} \mathrm{C}$ within 6 hours and maintain at $33^{\circ} \mathrm{C}-35^{\circ} \mathrm{C}$. When ICP became normal within 48 hours, the rewarming was started by controlling the temperature of the blanket to increase the rectal temperature from $36.5^{\circ} \mathrm{C}$ to $37.0^{\circ} \mathrm{C}$ for 12 hours. The breathing machine was applied if necessary. The heart rate, blood pressure, and muscle tone were monitored.

\section{Brain function and metabolism monitoring}

All the patients were monitored four times an hour for 72 hours. $\mathrm{P}_{\mathrm{bt}} \mathrm{O}_{2}, \mathrm{~S}_{\mathrm{jv}} \mathrm{O}_{2}, \mathrm{ICP}$, and CPP at a total of 10,944 time points were recorded and analyzed. Intubation of left radial artery was performed. ICP and CPP were detected by Intellivue Mp30 system (Philip, Amsterdam, the Netherlands). A $0.5 \mathrm{~mm}$ testing probe was inserted into the frontal lobe at a depth of 27-36 mm to detect $\mathrm{P}_{b t} \mathrm{O}_{2}$. The brain oxygen and temperature detector LICOR-II (Integra NeuroSciences
Limited, Plainsboro, NJ, USA) and Nova-H Monitor (Nova Biomedical Corporation, Waltham, MA, USA) were introduced to continuously examine $\mathrm{P}_{\mathrm{bt}} \mathrm{O}_{2}$ and $\mathrm{S}_{\mathrm{jv}} \mathrm{O}_{2}$ throughout the MHT for 7 days.

\section{Statistical analysis}

All the statistical analyses were conducted by SPSS software 13.0. All the continuous data were shown as mean \pm SD. The categorical data were tested by chi-square test. $\mathrm{P}_{\mathrm{bt}} \mathrm{O}_{2}, \mathrm{~S}_{\mathrm{jv}} \mathrm{O}_{2}$, ICP, and CPP data at different time points were tested by repeated-measure data analysis of variance. Rank-sum test was used to test the outcome among groups. It was considered to be statistically significant, if $P<0.05$.

\section{Results}

\section{Demographic and clinical characteristics}

There were 39 male and 29 female patients with sTBI. The onset age was $37.8 \pm 11.9$ years (ranging between 18 years and 72 years; Table 1). Glasgow Outcome Scale Score at admission was $5.3 \pm 1.2$ (ranging between 3 and 8 ). Thirty-one patients underwent surgery, and the other 37 patients accepted conservative therapy. Traffic accident $(n=31)$, beating $(n=21)$, and falling injury $(n=16)$ were the causes of sTBI. Epidural hematoma $(n=5)$, subdural hematoma $(n=9)$, brain parenchyma hematoma $(n=4)$, cerebral contusion and laceration $(n=10)$, diffusive axonal injury $(n=8)$, multiple injuries $(n=13)$, cranial basal bone fracture $(n=14)$, and brain hernia $(n=8)$ were detected by craniocerebral computed tomography (CT) scan.

Table I Demographic and clinical characteristics

\begin{tabular}{ll}
\hline & sTBI patients \\
\hline Sex, $\mathrm{n}(\%)$ & $39(57.4)$ \\
Male & $29(42.6)$ \\
Female & $5.3 \pm 1.2(3-8)$ \\
GCS score, mean \pm SD (range) & \\
Causes of sTBI, $\mathrm{n}(\%)$ & $31(45.6)$ \\
Traffic accident & $21(30.9)$ \\
Beating injury & $16(23.5)$ \\
Falling injury & \\
Treatment, $\mathrm{n}(\%)$ & $31(45.6)$ \\
Surgery & $37(54.4)$ \\
Conservative therapy & $37.8 \pm 11.9(18-72)$ \\
Age (years), mean \pm SD (range) & \\
CT imaging, $\mathrm{n}$ (\%) & $5(7.3)$ \\
Epidural hematoma & $9(13.2)$ \\
Subdural hematoma & $4(5.9)$ \\
Brain parenchyma hematoma & $10(14.7)$ \\
Cerebral contusion and laceration & $8(1 \mathrm{I} .8)$ \\
Diffusive axonal injury & $13(19.1)$ \\
Multiple injuries & $14(20.6)$ \\
Cranial basal bone fracture & $8(1 \mathrm{I} .8)$ \\
Brain hernia &
\end{tabular}

Abbreviations: CT, computed tomography; GCS, Glasgow Coma Scale; sTBI, severe traumatic brain injury; $S D$, standard deviation. 

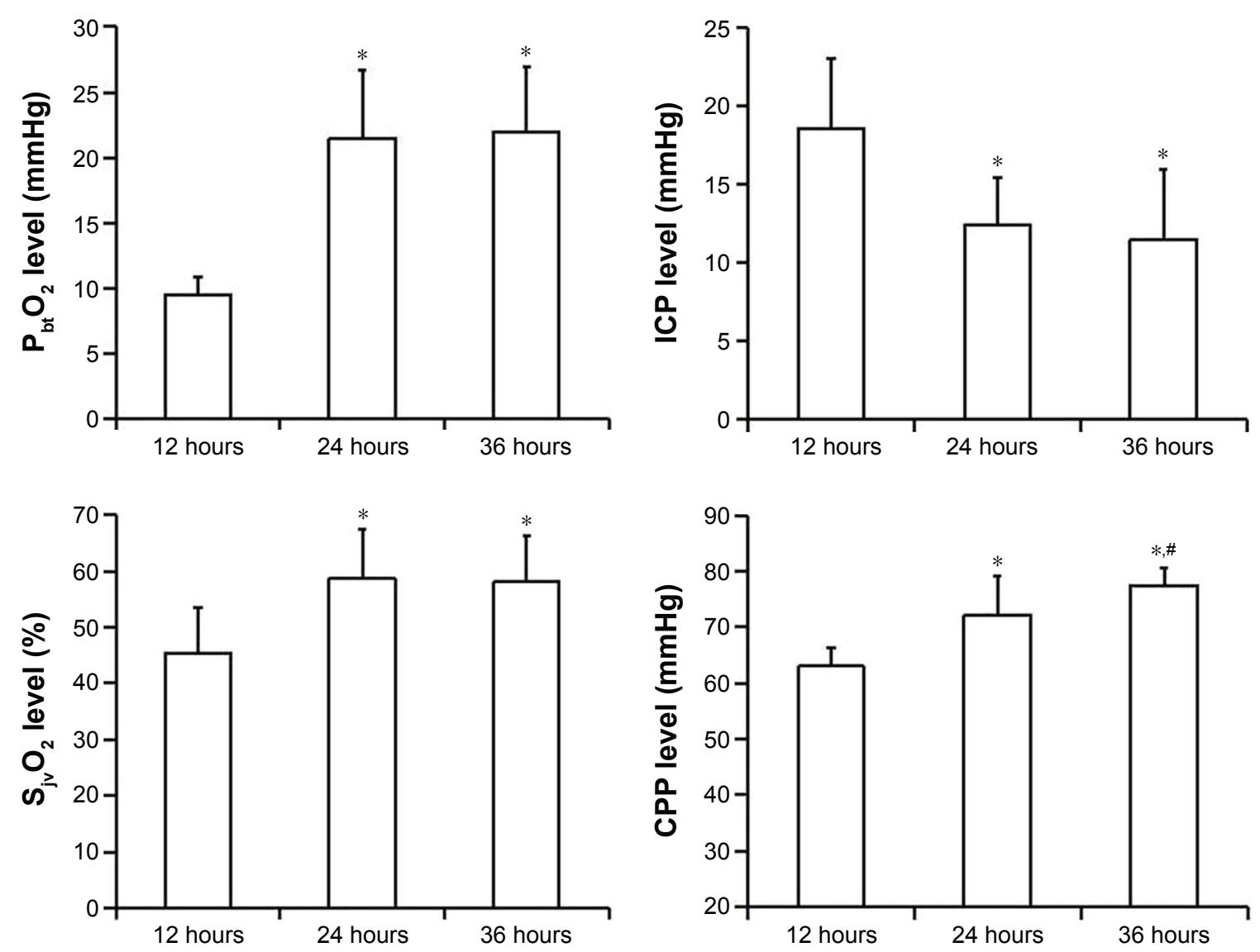

Figure I Comparison of data on $\mathrm{P}_{\mathrm{bt}} \mathrm{O}_{2}, \mathrm{~S}_{\mathrm{N}} \mathrm{O}_{2}, \mathrm{ICP}$, and CPP at 12 hours, 24 hours, and 36 hours after MHT.

Notes: *vs 12 hours $(P<0.05)$; " vs 24 hours $(P<0.05)$.

Abbreviations: CPP, cerebral perfusion pressure; ICP, intracranial pressure; $M H T$, mild hypothermia treatment; $\mathrm{P}_{\mathrm{bt}} \mathrm{O}_{2}$, brain tissue partial pressure of oxygen; $\mathrm{S}_{\mathrm{iv}} \mathrm{O}_{2}$, jugular venous oxygen saturation.

\section{Correlation of $\mathrm{P}_{\mathrm{bt}} \mathrm{O}_{2}$ with $\mathrm{S}_{\mathrm{jv}} \mathrm{O}_{2}, \mathrm{ICP}$ and CPP}

The mean $\mathrm{P}_{\mathrm{bt}} \mathrm{O}_{2}, \mathrm{~S}_{\mathrm{jv}} \mathrm{O}_{2}$, and CPP were obviously increased, but ICP was decreased at 12 hours under MHT (Figure 1). At 24 hours and 36 hours, no remarkable changes of $\mathrm{P}_{b t} \mathrm{O}_{2}$ and $\mathrm{S}_{\mathrm{jv}} \mathrm{O}_{2}$ were observed. Further analysis showed that $\mathrm{P}_{\mathrm{bt}} \mathrm{O}_{2}$ and ICP were negatively correlated $(r=-0.936, P<0.05)$. $\mathrm{P}_{\mathrm{bt}} \mathrm{O}_{2}$ and $\mathrm{S}_{\mathrm{jv}} \mathrm{O}_{2}(r=0.966, P<0.05)$, and $\mathrm{P}_{\mathrm{bt}} \mathrm{O}_{2}$ and CPP $(r=0.956, P<0.05)$ were positively linearly correlated after treatment with MHT for 24 hours. $\mathrm{P}_{b t} \mathrm{O}_{2}<10 \mathrm{mmHg}$ for $>10$ minutes was found in 56 patients, while only 21 patients had $\mathrm{S}_{\mathrm{jv}} \mathrm{O}_{2}<55 \%$ for $>10$ minutes (Table 2 ). There were still a high percentage of patients who had normal CPP but low $\mathrm{P}_{b t} \mathrm{O}_{2}$.

Table 2 Detection of $\mathrm{P}_{\mathrm{bt}} \mathrm{O}_{2}$ and $\mathrm{S}_{\mathrm{jv}} \mathrm{O}_{2}$ in 68 patients after MHT

\begin{tabular}{lll}
\hline Parameters & $\geq$ Mean value & $<$ Mean value \\
\hline $\mathrm{S}_{\mathrm{jv}} \mathrm{O}_{2}, \mathrm{n}(\%)$ & $47(69.1)$ & $21(30.9)$ \\
$\mathrm{P}_{\mathrm{bt}} \mathrm{O}_{2}, \mathrm{n}(\%)$ & $22(32.4)$ & $46(67.6)$ \\
\hline
\end{tabular}

Abbreviations: $\mathrm{MHT}$, mild hypothermia treatment; $\mathrm{P}_{\mathrm{bt}} \mathrm{O}_{2}$, brain tissue partial pressure of oxygen; $\mathrm{S}_{\mathrm{jv}} \mathrm{O}_{2}$, jugular venous oxygen saturation.
$\mathrm{P}_{b t} \mathrm{O}_{2}$ as a prognostic factor for sTBI

All the patients were divided into two groups, based on $\mathrm{P}_{\mathrm{bt}} \mathrm{O}_{2}$ at admission. There were 46 patients in group $\mathrm{A}\left(\mathrm{P}_{\mathrm{bt}} \mathrm{O}_{2} \leq 10 \mathrm{mmHg}\right)$ and 22 in group $\mathrm{B}\left(\mathrm{P}_{\mathrm{bt}} \mathrm{O}_{2}>10 \mathrm{mmHg}\right)$. Survival data showed that eight patients died and five were in vegetative state in group A; no patients died or were in vegetative state in group B (Table 3). Statistical analysis indicated that low $\mathrm{P}_{\mathrm{bt}} \mathrm{O}_{2}$ was significantly associated with poor outcome $(P<0.01)$.

Table 3 Association of $\mathrm{P}_{\mathrm{bt}} \mathrm{O}_{2}$ with patients' outcome

\begin{tabular}{|c|c|c|c|}
\hline \multirow[t]{2}{*}{ Outcome } & \multicolumn{2}{|l|}{$\mathbf{P}_{b t} \mathbf{O}_{2}$} & \multirow[t]{2}{*}{$P$-value } \\
\hline & $\begin{array}{l}\leq 10 \mathrm{mmHg} \\
(\mathrm{n}=46)\end{array}$ & $\begin{array}{l}>10 \mathrm{mmHg} \\
(\mathrm{n}=22)\end{array}$ & \\
\hline Dead, n (\%) & $8(17.4)$ & $0(0.0)$ & 0.145 \\
\hline \multicolumn{4}{|l|}{ Alive, n (\%) } \\
\hline Vegetative state & $5(10.9)$ & $0(0.0)$ & \\
\hline Severe disability & $4(8.7)$ & $6(27.3)$ & \\
\hline Moderate disability & $7(15.2)$ & $6(27.3)$ & \\
\hline Good & $22(47.8)$ & $10(45.5)$ & \\
\hline
\end{tabular}

Abbreviation: $\mathrm{P}_{\mathrm{bt}} \mathrm{O}_{2}$, brain tissue partial pressure of oxygen. 


\section{Discussion}

In recent years, the application of $\mathrm{P}_{\mathrm{bt}} \mathrm{O}_{2}$ monitoring in the management of severe brain trauma is getting more and more attention. Compared with $\mathrm{S}_{\mathrm{jv}} \mathrm{O}_{2}, \mathrm{P}_{\mathrm{bt}} \mathrm{O}_{2}$ has the advantage of being objective and rarely influenced. ${ }^{6,7}$ Although $\mathrm{P}_{\mathrm{bt}} \mathrm{O}_{2}$ is a reliable parameter and could be monitored for a long observation period, it is still unable to manifest the overall brain function, especially in the probe placing site along with high metabolic area or low blood supply. Local $\mathrm{P}_{b t} \mathrm{O}_{2}$ value may be misinterpreted as the $\mathrm{P}_{b t} \mathrm{O}_{2}$ of the whole brain. Thus, there is controversy on the accuracy of $\mathrm{P}_{\mathrm{bt}} \mathrm{O}_{2}$. Gopinath et $\mathrm{al}^{8}$ demonstrated that patients without decreased $\mathrm{S}_{\mathrm{jv}} \mathrm{O}_{2}$ had good prognosis. However, mortality in these patients was still much higher than that in patients without $\mathrm{P}_{b t} \mathrm{O}_{2}<10 \mathrm{mmHg}$ or with $\mathrm{P}_{\mathrm{bt}} \mathrm{O}_{2}<10 \mathrm{mmHg}$ for $<30$ minutes. $\mathrm{P}_{\mathrm{bt}} \mathrm{O}_{2}$ may be decreased while $\mathrm{S}_{\mathrm{jv}} \mathrm{O}_{2}$ is still within normal range, indicating that $\mathrm{P}_{\mathrm{bt}} \mathrm{O}_{2}$ as a parameter is more sensitive than $\mathrm{S}_{\mathrm{jv}} \mathrm{O}_{2}$. In our patient cohort, the percentage of patients with low $\mathrm{P}_{\mathrm{bt}} \mathrm{O}_{2}$ was high. There were 56 patients with $\mathrm{P}_{b t} \mathrm{O}_{2}<10 \mathrm{mmHg}$ for $>10$ minutes, while 21 patients had $\mathrm{S}_{\mathrm{jv}} \mathrm{O}_{2}<55 \%$ for $>10$ minutes.

We also found that $\mathrm{P}_{b t} \mathrm{O}_{2}$ was positively correlated with CPP. $\mathrm{P}_{b t} \mathrm{O}_{2}$ is mainly influenced by CPP, when arterial pressure of carbon dioxide and oxygen keeps stable. The increase in CPP could improve $\mathrm{P}_{\mathrm{bt}} \mathrm{O}_{2}$, which contradicts with the conclusion by Kiening et al. ${ }^{9}$ They demonstrated that $\mathrm{P}_{\mathrm{bt}} \mathrm{O}_{2}$ was stable when CPP was $>60 \mathrm{mmHg}$, which was associated with the detection methods. In this study, we placed the probe in the ischemic area near the brain trauma, while Kiening put the probe in the non-ischemic area. In addition, automatic regulation dysfunction is always present in ischemic tissue. What is more, low $\mathrm{P}_{b t} \mathrm{O}_{2}$ could coexist with normal CPP. However, normal CPP has no relation with good cerebral blood supply in patients with TBI.${ }^{10}$ In acute brain trauma, both low CPP and changes of local cerebral vessels including microcirculatory injury and spasm, stenosis, and embolism of large vessels contribute to the ischemia. ${ }^{11,12}$ Normal CPP could exclude the diagnosis of local ischemia and hypoxia in brain tissue.

ICP is another key factor in the treatment of brain trauma. Increased ICP directly decreases CPP, leading to the insufficient cerebral blood supply and low $\mathrm{P}_{\mathrm{bt}} \mathrm{O}_{2}$. McKinley et $\mathrm{al}^{13}$ have ever established a dog model of high ICP, and the similar results were found. Besides, hypoxia is associated with poor outcome in patients with brain trauma. van Santbrink et $\mathrm{al}^{14}$ analyzed 22 patients with TBI and proved that most patients had a low cerebral oxygen period after TBI. In our study, 46 patients underwent $\mathrm{P}_{\mathrm{bt}} \mathrm{O}_{2}<10 \mathrm{mmHg}$ within 24 hours after TBI, eight of whom died and five patients were in vegetative state for 6 months. On the contrary, no death and vegetative state were observed in 22 patients with normal $\mathrm{P}_{\mathrm{bt}} \mathrm{O}_{2}$. All the evidence supports that $\mathrm{P}_{\mathrm{bt}} \mathrm{O}_{2}$ is closely correlated with patients' outcome.

\section{Conclusion}

Our findings demonstrated that the combination of $\mathrm{P}_{b t} \mathrm{O}_{2}$, $\mathrm{S}_{\mathrm{jv}} \mathrm{O}_{2}$, ICP, and CPP could help guide the management and predict the outcome for patients with sTBI.

\section{Acknowledgment}

This work was supported by the National Natural Science Foundation of China (814712751004949).

\section{Disclosure}

The authors report no conflicts of interest in this work.

\section{References}

1. Lee JC, Rittenhouse K, Bupp K, et al. An analysis of Brain Trauma Foundation traumatic brain injury guideline compliance and patient outcome. Injury. 2015;46(5):854-858.

2. Hawley CA, de Burgh HT, Russell RJ, Mead A. Traumatic brain injury recorded in the UK Joint Theatre Trauma Registry among the UK Armed Forces. J Head Trauma Rehabil. 2015;30(1):E47-E56.

3. Elefteriades JA, Ziganshin BA. Protecting the brain: do we know the way? J Thorac Cardiovasc Surg. 2015;149(2 suppl):S74-S75.

4. Li YH, Zhang CL, Zhang XY, Zhou HX, Meng LL. Effects of mild induced hypothermia on hippocampal connexin 43 and glutamate transporter 1 expression following traumatic brain injury in rats. Mol Med Rep. 2015;11(3):1991-1996.

5. Zhang BF, Wang J, Liu ZW, et al. Meta-analysis of the efficacy and safety of therapeutic hypothermia in children with acute traumatic brain injury. World Neurosurg. 2015;83(4):567-573.

6. Grmec S, Klemen P. Early ventilation in traumatic brain injury. Resuscitation. 2008;77(3):417-418; author reply 418.

7. Davis DP, Idris AH, Sise MJ, et al. Early ventilation and outcome in patients with moderate to severe traumatic brain injury. Crit Care Med. 2006;34(4):1202-1208.

8. Gopinath SP, Valadka AB, Uzura M, Robertson CS. Comparison of jugular venous oxygen saturation and brain tissue Po2 as monitors of cerebral ischemia after head injury. Crit Care Med. 1999;27(11): 2337-2345.

9. Kiening KL, Unterberg AW, Bardt TF, Schneider GH, Lanksch WR. Monitoring of cerebral oxygenation in patients with severe head injuries: brain tissue PO2 versus jugular vein oxygen saturation. $J$ Neurosurg. 1996;85(5):751-757.

10. Badjatia N, Carney N, Crocco TJ, et al; Brain Trauma Foundation; BTF Center for Guidelines Management. Guidelines for prehospital management of traumatic brain injury 2nd edition. Prehosp Emerg Care. 2008;12(suppl 1):S1-S52.

11. Balestreri M, Czosnyka M, Hutchinson P, et al. Impact of intracranial pressure and cerebral perfusion pressure on severe disability and mortality after head injury. Neurocrit Care. 2006;4(1):8-13.

12. Wang D, Zhang J. Effects of hypothermia combined with neural stem cell transplantation on recovery of neurological function in rats with spinal cord injury. Mol Med Rep. 2015;11(3):1759-1767.

13. McKinley BA, Morris WP, Parmley CL, Butler BD. Brain parenchyma $\mathrm{PO} 2, \mathrm{PCO} 2$, and $\mathrm{pH}$ during and after hypoxic, ischemic brain insult in dogs. Crit Care Med. 1996;24(11):1858-1868.

14. van Santbrink H, Maas AI, Avezaat CJ. Continuous monitoring of partial pressure of brain tissue oxygen in patients with severe head injury. Neurosurgery. 1996;38(1):21-31. 


\section{Publish your work in this journal}

Neuropsychiatric Disease and Treatment is an international, peerreviewed journal of clinical therapeutics and pharmacology focusing on concise rapid reporting of clinical or pre-clinical studies on a range of neuropsychiatric and neurological disorders. This journal is indexed on PubMed Central, the 'PsycINFO' database and CAS, and is the official journal of The International Neuropsychiatric Association (INA). The manuscript management system is completely online and includes a very quick and fair peer-review system, which is all easy to use. Visit http://www.dovepress.com/testimonials.php to read real quotes from published authors.

\footnotetext{
Submit your manuscript here: http://www.dovepress.com/neuropsychiatric-disease-and-treatment-journal
} 